\title{
The Right to Privacy in the Iranian Criminal Justice System
}

\section{Iran Ceza Hukuku Sisteminde Özel Hayatın Korunması}

\section{Mansour RAHMDEL ${ }^{1 \oplus}$}

${ }^{1}$ Assist. Prof., Tehran Islamic Azad University, Faculty of Law, Central Branch, Tehran, Iran

\section{ABSTRACT}

That the individual shall have full protection in person and in property is a core principle of a reasonable life. In some societies this principle is ignored in different ways. At times, government brings some security excuses. "In these societies, the old forms of the right to privacy are seldom known by people, let alone the new forms."

Despite kinds of inattention in these societies, we can see some aspects of the right to privacy, we can see people that pay attention to this right. They respect this right and try to develop its concept. They are trying to get some sanctions for its infringement. So, it has been found necessary from time to time to redefine the exact nature and extent of such protections. Political, social, and economic changes entail the recognition of new rights. So, gradually, the scope of these rights has broadened; and now the right to life has come to mean the right to enjoy life. The right to safety and the right to liberty secure the exercise of extensive civil privileges. The present paper, which uses an analytical method, considers the situation of Iranian criminal justice.

Keywords: Right, privacy, Iran 


\section{Introduction}

Human beings have two dimensions. On the one hand, they are autonomous and on the other, they are regarded as a social animals who part of a society and relate to others. These dimensions are not separable and society must accept autonomy and its requirements.

As a result of man's presence in society, he deserves rights in relation to his physical and psychological integrity. So, the right to privacy for someone who lives alone and without any connections with others, is meaningless.

The right to privacy is regarded as a fundamental right for human beings which should be protected as a human rights which has a deep connection with his personality. 'It is important to distinguish between privacy as a human right and privacy interests as the object of statutory protection. Human rights serve to protect interests which are fundamental to human dignity. They are enshrined in constitutions and in international law and their status is such that states may pass no laws or take any action in breach of their guarantees. The protection provided by ordinary laws is of a lesser order. Ordinary laws prohibit certain types of conduct, such as littering or drunk driving. These laws, however, are not constitutional in nature and have no overriding status. ${ }^{1}$ Human being's autonomous personality requires the right to be left alone, the right to be treated with discretion, the right to live without others' control and inspection and the right to keep one's private life secret. It is worth noting that the concept of the right to privacy has been developed and affected by scientific, social, economic and other factors in the passage of time. Therefore, its concept and realm in a developed and modern society differs from a traditional society. 'Privacy depends on the societal situation as a whole. So do invasions of privacy.'

In a modern society, in which new technology is used, not only does the police monitor other people's lives via cameras and obtain confidential information about individuals, but ordinary members of the public can do so too, yet they have no right this private information. Hidden cameras and telephones which take photos and films, as well as E-mail filters and other electronic devices are very easily being used

1 Toby Mendel, 'The Right of The Public to Know and Freedom of Entertainment: Information Seen From The Consumer's Angle In Freedom of Expression and The Right to Privacy' "Freedom of Expression And The Right to Privacy" Strasbourg Conference Reports 23 September 1999 (1999) 45.

2 Artzt Gunter, The Right to Respect for Privacy As Affected By Modern Scientific and Technical Devices, Legislative Trends and Conclusions, (1977) 6. 
to infringe on the right to privacy of people. It could thus be said that technology has developed the realm in which the right to privacy is infringed. Based on this context, the provision of new instruments to protect the right to privacy seems important.

The concept and realm of the right to privacy depends on the culture and government that rules the society. "There is a fundamental difference between a person's reasonable expectation of privacy in his or her dealings with the state and ordinary citizens.' ${ }^{3}$ Therefore, based on the religious or non-religious culture as well as the despotic, totalitarian or democratic political regime that rules the society, the concept and realm of privacy could be widened or restricted. 'When an authoritarian regime takes power, its first measures are usually to abolish freedom of expression and muzzle the press. Silence and obscurity are necessary for dictators. ${ }^{4}$

The Iranian government has ratified the Universal Declaration of Human Rights ${ }^{5}$ and the International Covenant on Civil and Political Rights as two of the most important international documents and has enacted some provisions about the right to privacy. Iranian culture and tradition, also, respects the right to privacy as a fundamental right.

Although the Universal Declaration of Human Rights has not referred to some new forms of the right to privacy, which have been created in the course of technological development, but, its general phrases and concepts such as "private life" cited in article 8 , include all the new forms of the right to privacy. Article 17 of the Covenant on Civil and Political Rights refers to the right of privacy. According to this article:

' 1 . No one shall be subjected to arbitrary or unlawful interference with his privacy, family, home or correspondence, nor to unlawful attacks on his honour and reputation.

2. Everyone has the right to the protection of the law against such interference or attacks." Regarding the accession of Iran to the Covenant, the legislator should pay

3 Mendel (n 1) 45.

4 Matthias Prinz, 'Remedies Against An Infringement of Privacy: The Effect of Sanctions and Compensation and Their Proportionality', "Freedom of Expression And The Right to Privacy" Strasbourg Conference Reports 23 September 1999 (1999) 69.

5 According to section 13 of this declaration: whoever his rights and freedom, as cited in this declaration, is infringed has the right to remedy before a national court in a convenient way, even if the infringement is done by the action of a person who acts as an official. And according to section 8: (1) everybody has the right to expect others to respect his or her private life, family, dwelling and correspondence. (2) In order to respect this right, the public authority cannot intervene, unless the law allows it. It is necessary for national security, public security and public welfare to prevent disorder and crime, to protect the health and morality or to protect others rights and freedom. 
attention to it when adopting human rights laws. Of course, the existing rules have also been affected by the Covenant.

So, it could be said that as it has been referred and guaranteed by Universal Islamic Declaration of Human Rights, (known as Cairo declaration) ${ }^{6}$ the Universal Declaration of Human Rights and the European Convention (ECHR).' 'Privacy is now widely recognized as a fundamental human right. Article 12 of the Universal Declaration of Human Rights also refers to the right of the individual to privacy. Therefore, in this regard, the Universal Declaration of Human Rights and the Cairo Declaration share, but the difference is that the basis of the law in the Cairo Declaration is Islamic law, but the Universal Declaration of Human Rights does not refer to any Sharia. The Iranian legislator takes into account both declarations in the passage of laws, and is naturally more inclined to the Cairo declaration because of the need for the Islamic laws to be.

The first part of the paper, considers the historical background, the owners of the right to privacy and its concept. The second part refers to the forms of the right to privacy and the way through which the Iranian Law protects this right. The problem is whether Iranian Law acknowledges this right, and if so, what forms of protection (criminal or civil) are implied.

\section{Part One: General Discussion}

The first part refers to the historical background and owners of the right to privacy and its different aspects.

\subsection{Historical Background}

The right to privacy in Iran in the past centuries was mainly derived from custom and was respected by people in their social relations. Children learn to respect others' privacy, not to infringe others' right and property. They are condemned for their wrong behaviour in society and at school. They are taught that they are not allowed

6 Article 18 refers to the right to privacy and provides "a. everyone has the right to live in security for himself, his faith, family, honor and belongings.

b. Everyone has the right to be independent regarding his private affairs in his house, family, wealth and communications. It is not allowed to spy upon him, have an eye on him or offend his reputation. He is to be protected against all arbitrary meddling.

c. Privacy of residences is to be respected in all cases, and they should not be trespassed unlawfully and without the owner's permission. They should not be pulled down, requisitioned, nor should their dwellers be driven out.".

7 Eric M Barendt, 'The Protection of Policy and Personal data and the right to use one's image and voice: when does the dissemination of information become an interference with a person's life?' in "Freedom of Expression And The Right to Privacy” Strasbourg Conference Reports 23 September 1999 (1999) 57. 
to interfere with everything. While a few texts where this right has been explicitly referred to can be found, but there is no legal text in which the legislator refers to it.

However, since European countries 'have abided by the Human Rights conventions and have signed the European Human Rights Convention, its concept in these countries is much broader than many other countries, including Iran. But, 'in comparison to the right to reputation, protected by defamation and libel laws, the right to privacy is relatively new. In the Anglo-American legal world, it did not emerge until the end of the nineteenth century, when a famous law review, the Harvard Law Review by Warren and Brandeis, argued that the common law implicitly recognized a right to privacy and that it was now time for the law to explicitly uphold this right in view of the increasing tendency of the press to spread gossip and scandal about prominent political and social figures. Several states in the USA have adopted a Privacy Right either as a result of legislation or by judicial decision, although a parallel development has not yet occurred in England. In Germany the right only clearly emerged from judicial decisions in the 1940s and 1950s; in France the right was put on a statutory basis as recently as 1970, although earlier court decisions had recognized it. Legally speaking, therefore, the right is a child of the mass media age. It reflects the need which most people feel to be let alone by the press and broadcasting media, their desire not to be harassed or observed by journalists and camera-men. At the same time, technical developments have made an invasion of privacy by longdistance cameras, bugging devices, and electronic data banks considerably easier, whether the violation is committed by the media, the police, banks or credit agencies. These developments have not only made more imperative the need to develop privacy rights in their traditional form, but have also influenced the scope of the right. ${ }^{8}$

In Italy, "the earliest judgments denied the existence of any right to privacy (riservatezza) in their legal system and the earliest cases of recognizing the right to privacy began to appear in the 1950s. In the Italian legal system, although there is no explicit provision on the point, it does recognize the existence of a right to privacy (riservatezza or privatezza)." 9

In France, the various manifestations of this right can be traced back to different times. For example "the Constitution of 22 August 1795 proclaimed that: 'Every

$8 \quad$ Ibid 58.

9 Alpa Guido, 'Protection of Privacy in Italian Law' in Basils Markesinis (eds), Protecting Privacy (Clarendon Press Oxford 1998) 114-115. 
citizen's home is an inviolable asylum.' The Constitution of 3 September 1791 and the Constitution of 13 December 1799 had provided similar protections. The statute of 11 May 1868 criminalized the publication of any 'fact relating to private life' and in 1970 the new Article 9 of the Civil Code was incorporated and recognized a 'general right to privacy'. But it was only in 1995 that the Constitutional Council consented to consecrate the 'right to privacy' as a constitutional right or, more accurately, as a 'constitutional principle'. ${ }^{10}$ But, in England, contrary to Italy and France, 'legal systems are unusual in that they have hitherto not recognized autonomous rights of action to protect privacy' ${ }^{11}$ and there is no general rule to protect the right to privacy. According to the Times Newspaper 4 January 2002 the Appeal court provided: 'there is no civil liability for breach of the right to privacy but Lord Sedley stated: The English Law recognizes the right to privacy and protects it in a convenient way. He regards the right to privacy as a qualified right and which is protected by English law.' ${ }^{12}$

The writer tries to set forth a new approach for conceptualizing privacy. In doing so, at first I enumerate the owners of the right, as, its enumeration can help us to determine the threshold of the right.

\subsection{The owners of the right to privacy}

It seems that, every human being regardless of their nationality, age, gender, religion, civil ability or abnormality and authority have the right to privacy. Even corporations have the right to privacy, because of their presence and activity in society, similar to natural persons. 'The right to privacy should belong in its full extent to any living person, to a certain extent, the protection of this right should also be assured after the death of such person. Legal persons and other organizations and groups should also have such right in so far as, by its nature, it is applicable to them". ${ }^{13}$

\subsubsection{Foreigners}

Iran-residing foreigners, as well as Iranians, have the right to privacy in cases where the law recognizes it. According to Article 961 of the Iranian Civil Code,

10 Picard Ettienne, 'The Right to Privacy in French Law' in Basils Markesinis (eds), Protecting Privacy (Clarendon Press Oxford 1998) 49-50.

11 Barendt (n 7) 57.

12 Spencer Maureen\& Spencer Nutcases, Human Rights, (Sweet \& Maxwell 2002) 115-116.

13 Report of The Committee of Experts On Human Rights to The Committee of Ministers On The Right to Respect For Privacy, (Strasbourg, 1973). 
foreigners deserve all the rights much the same as Iranian nationals, unless the code has explicitly banned the foreigners from some rights or some rights that belong only to Iranians. The reason is that, everybody as a human being has his own dignity and as the right to privacy is one of the grounds of the human being's dignity, it is respected for all people, irrespective of their nationality.

\subsubsection{Dead persons}

Regarding Article 956 of the Iranian Civil Code (the capacity to have the rights begins with birth and finishes with death) it might be inferred that the dead person does not enjoy the right to privacy. Here we should note some issues:

\section{(1) Revealing the secrets or facts related to the period of life time}

Here we can consider some acts that the dead have done in their life time or the secrets revealed after death. In some cases, some persons have infringed the right to privacy before death and now it is argued that this kind of infringement is regarded as an infringement to the right to privacy of the heirs.

\section{(2) Revealing the secrets and facts related to the period after death}

Here we can consider some issues that happen during the funeral ceremony.

With regard to information about the life of a deceased individual revealed after death, there is no legal protection unless this kind of revelation infringes the heir's right to privacy. For example, Item 2 of Article 30 of the Press Code, ratified on $1985 / 3 / 19$, states that "if published text contains matters like accusation, slander, affront or slang words to the dead person but according to custom insults the heirs, each of them can prosecute the perpetrator."

According to professor Ashouri in Iran, the civil case posed by the heirs, in the case of insult to the dead person's memories should be regarded as a personal case and not a case on behalf of the dead person."14

\subsubsection{Public Figures}

"Public figure" covers a very broad range. The achievement of public office, of eminence in the arts, sciences, the theatre, sports, any activity in politics, prominence in society or the slightest notoriety make a person a public figure. ${ }^{15}$

14 Mohammad Ashouri, Criminal procedure (First Volume Samt Publications 2016) 261.

15 Samuel H Hofstadter, The Right of Privacy (Central Book Company 1964) 48. 
Undoubtedly, public figures have their own privacy and merely being a public figure does not mean that people are free to look for everything about them. They have privacy for their family secrets. It seems that public figures and especially "the President of a Republic needs a private life and is entitled to have it protected by the law." 16 But, they do not have the right to privacy like other people. For example, their economic, social and political status is controlled by mass media. The law puts a bound on them to inform the government about their property. It seems that an official figure or any kind of 'public agent', when performing his duties, does not exercise, by implication, his or her private activities. For example, according to Article 156 of the Islamic Penal Code, people have the right to self-defence, when the officials abuse their power. In these cases, the audience might breach their physical integrity or might take some photos or film to prove their identity.

In French law, "an official figure or any kind of 'public agent' while fulfilling his functions, is not entitled to claim the protection of his privacy, and one may thus take and publish a photo of his image, at least when he is in a public place."17

On 19 December 1995, the German Bundesverfassungsgerichtshof decided for the first time in a leading case that the protection of privacy is not limited to the domestic sphere, one's 'own four walls', but a protected private life can also occur in places which are accessible to the public, and that reporting from this sphere without the person's agreement may therefore be inadmissible. The justification for that was that it makes a difference whether a limited number of people just happen to be at a certain public location and therefore witness certain aspects of private life, or whether these events are fixed in photographs or in writing and then made accessible to millions of people. The protection of the private sphere in public places is very limited in Germany for so-called 'personen der Zeitgeschichte' (public figures), who can only forbid photos taken in those public places when they are shown in a situation of particular confidentiality, taking place in 'secluded surroundings'. ${ }^{18}$

\subsubsection{Wife and Husband}

The right to privacy between wife and husband is especially meaningful. Each of them, because of their independent personality can deter the other from infringement

16 Etienne (n 10) 79

17 Ibid 79.

18 Prinz (n 4) 70. 
to the other's privacy. It is a wrong to imagine that the man has an absolute right to interfere with every aspects of his wife's life. As we regard a woman and a man equal, this equality should reveal itself in every field. The wife has her own secrets, her own privacy.

Regarding one of the most important aspects of the relationship between a woman and a man, which is sex, there are different inferences in different societies, which are mainly influenced by the culture of the society. So, it could be said that "The great peculiarity of the privacy cases is their predominant, though not exclusive, focus on sexuality - not "sex" as such, of course, but sexuality in the broad sense of that term: the network of decisions and conduct relating to the conditions under which sex is permissible, the social institutions surrounding sexual relationships, and the procreative consequences of sex. Nothing in the privacy cases says that the doctrine must gravitate around sexuality. Nevertheless, it has." ${ }^{19}$ But, in Iranian Law, although it has not been explicitly written in the law, as it is inferred from the whole concepts of the Iranian civil code, the wife, in any case, has to have sexual intercourse with her husband and cannot disobey. But, it seems that the non-desire of the wife to have sexual intercourse (from anus or vagina) should be respected as her privacy. In other word, the wife does not say that she disobeys her husband, but, she says that she cannot have sexual intercourse at the time that the husband wants, so, her opinion must be respected.

In Iranian Law, which is influenced by Islamic Shiite Law, the Legislator does not respect the wife's right to privacy. So in this case, we must leave it to the personal relationship between the wife and the husband to resolve it in a convenient way. But, in other countries' laws, like the United Kingdom, the legislator respects the wife's right to privacy and provides that, not only must the sexual intercourse be done by the consent of the wife, but also the continuance of the intercourse must be by her consent otherwise the act will be an offence. ${ }^{20}$

\subsubsection{Legal Entities}

Here, the question is that whether legal entities have the right to privacy.

In reply, it might be argued that the right to privacy has been acknowledged only

19 Jed Rubenfeld, “The Right of Privacy" in [1989] 102 Harward Law Report, (1989) 707-807

20 Andrew Ashworth, Principles of Criminal Law (Tony Honore \& Joseph Raz eds, Clarendon Press, Oxford 1992) 302. 
for human beings and the human being's dignity requires it and since the legal entities are not human, they have no right to privacy.

Iranian Trade Law in Article 588 provides that: The legal entity owns all the rights and bears all the duties that the law has provided for natural persons in exception of rights and duties that naturally the humankind can own such as the rights and duties of being a father or child and so on. On this basis, we can suppose some of the rights to privacy for legal entities.

The point is that a legal entity, for example a trade company, currently needs to compete with other companies in the world of trade, so that without competing, it cannot continue its work and may go bankrupt. So, it expects the employees to keep the secrets and not to reveal them. In Turkey, "Corporation privacy and business secrets are protected under the economy, industry, and trade section of the Turkish Penal Code. ${ }^{21}$

\subsection{Concept of the right to privacy}

"Traditionally, the right to privacy would refer to people's interest for property and especially the Land." 22 In addition to land and property we can refer to the secrets of the family. The reason that the right to privacy in old time had a limited concept is that in old life there was a close relationship between people and as we see, wherever the relationship is closer, the right to privacy is weaker. In other words, the closer the relationship, the weaker the right to privacy. But, nowadays the development of science has expanded the sphere of the right to privacy and has created some new areas for it, so that 'currently, privacy is a sweeping concept, encompassing (among other things) freedom of thought, control over one's body, solitude in one's home, control over information about oneself, freedom from surveillance, protection of one's reputation, and protection from searches and interrogations. Time and again philosophers, legal theorists, and jurists have lamented the great difficulty in reaching a satisfying conception of privacy'. ${ }^{23}$

As mentioned before, the right to privacy is interwoven with different issues such as culture, political regime that rules the country and so forth. This renders the concept

21 Büşra Demiral Bakırman, 'The Protection of Trade, Banking, and Customer Secrets in Turkish Criminal Law' (2017) 5(2) Journal of Penal Law and Criminology 107, 118.

22 Brain Neil, 'Privacy, A Challenge for the Next Century' in Basils Markesinis, Protecting Privacy, (Clarendon Press Oxford 1998) 2.

23 Daniel J Solovet, Conceptualizing Privacy, (1992), CLR 90, 1089. 
of privacy difficult to define. Lapse of time also influences its definition. So, some cases were included in it in the past and now are excluded and vice versa.

The relation between the culture and the right to privacy is one of the most important issues, and thus should be considered more precisely. In fact it could be said that everything stems from culture. It is the culture that determines the realm of the right to privacy. It is the culture that limits or expands its realm. It is because of the culture that we see different conceptions of the right to privacy. Culture influences everything in the society. The cultural differences in different societies have brought different concepts. Even when we consider the difference of the time and place and their effect on the concept of privacy, in fact it is the developments of the culture that influences the concept, and not the time or the place. In Italian law, the Highest Court recognized the right to privacy in the case of Soraya. ${ }^{24}$ They identified three different meanings, as follows (starting from the narrowest meaning): (i) domestic privacy (intimita), which is linked to the protection of the home, to which the court states that a human being has the 'right to be let alone'; (ii) the realm of individual and family life, and certain forms of illicit, interpersonal intimacy in relationships, including outside of home and in correspondence; (iii) riserbo, or the right to require other people's discretion about one's private life, or privacy. Applying the 'general principles of the legal system' the Court held that the first definition was too restrictive, the second more 'reasonable', and the third too broad and general.

The Court also specifies that a rigid definition of privacy (riservatezza) is not appropriate, since it needs 'flexibility as to its precise content' in order for it to be adapted 'to the needs of (different) environments, places and times' ${ }^{25}$

In Iranian Law, the right to privacy has not been defined and also the phrase of "the right to privacy" has not been mentioned. So, it seems difficult to define the right to privacy. Since, as mentioned before, the concept of the right to privacy is related with culture, society, economy and especially the ruling political regime in every

24 The case of Soraya is extremely simple. A news weekly devoted specifically to events in the lives of royal families, and constantly circulating among the wider public, had photographs - taken with a telephoto lensprepared for publication (but had not yet been published). They showed the Princess Soraya behaving affectionately with an actor inside her Roman villa. At that time the Princess, who had formerly been the Czarina of Persia, was living in exile, having been abandoned by her husband because of her inability to conceive children. It was also known that she had been granted an annuity, subject to the condition that she led a chaste and exemplary life. This was what gave rise to Princess's claim, both for breach of her rights over her visual image and for breach of her right to privacy and for trespassing in her home. 
country and perhaps something is included in this right in one country and is excluded in another one. So, it is relative and its concept differs from one country to another. It could be said that "privacy is not a single conception but a loose amalgam of different interests difficult to combine in one formulation' ${ }^{26}$

Nevertheless, we can, in general, define the right to privacy as follows: The right to privacy is some aspects of life that are completely personal and relating to the family regarding which the public and third parties are not concerned and its realm is determined by law, custom and the owner of the right usually expects others to respect it. "Privacy may be usefully defined as "the claim of individuals", groups, or institutions to determine for themselves when, how, and to what extent information about them is communicated to others. ${ }^{27}$ 'In the name of privacy are defended diverse concerns as the right to be free from intrusive police searches, from wiretapping, from persistent journalists, and so on; the right to make private decisions, particularly in relation to intimate family concerns (abortion or contraception, for instance); and the right to have some control over the collection, storage, and disclosure of personal information (by government, financial institutions, medical organizations, educational establishments, and others). ${ }^{28}$ It should be noted that protected private life can also occur in a public place. A public place does not automatically lead to the presumption that the photographed activity is a public activity. Even in a public place (where usually being nude is allowed, like walking on the beach in swim suite) everybody who is nude, or has a lovely relationship with her/his partner has her/his own privacy, and it does not mean that everybody is allowed to take photos or films of the scene. So, it seems that there is an unlimited concept of the private sphere, without any restrictions to certain rooms or spaces. In other words, privacy is not limited to the private places. In next part we will consider some forms and kinds of the right to privacy in Iranian Law.

\section{Part Two: Samples of the Right to Privacy}

The traditional samples of the right to privacy are the right to privacy to life, respect, dwelling, letters and secrets and in a general word, the right to communications and information. In recent years, publication and distribution of people's photos without their consent has been regarded as an infringement of their right to privacy. 
Regarding these kinds of rights to privacy, the problem is that 'the standard models of property rights seem unsuitable to achieving information privacy goals. ${ }^{29}$ So, new tools are required to preserve and protect these kinds of rights.

We consider the samples of the right to privacy in three sections as follows:

\subsection{The right to privacy to property, Dwelling, Physical and Psychological} Integrity

\subsubsection{The right to privacy to property}

One of the material dimension of human's life is properties which the human being has in his possession. He is endorsed by these properties and by reliance on the properties he can go on in his life expecting a hopeful life. The property, as it is usual, is earned by the man and may be owned as a result of heritage or other legal acts. Property is either tangible or intangible. Everybody likes to keep the secrets of his property. Nobody has a right to get information about others property, how they earn it, how they spend it and how much have they get it. The estimation of the property could have two different dimensions. One of them in fact is the secrecy that relates to the property, as it was explained and the other is the physical aspect of the property that determines others to enter in it without the consent and permission of the owner.

Iranian Constitution in article 22 protects the right to property and also some other statutes like articles 30-39 and 327-328 of the Civil Code and articles 158-177 of the Civil Procedure Law and articles 690-694 of the Penal Code have provided some protections.

\subsubsection{The right to privacy to Dwelling}

\subsubsection{Definition of Dwelling}

The dwelling, among the properties, is given special importance, because man uses it for his welfare. There is nowhere more private for man. It is therefore regarded as with utmost importance in society and told that there is no place like home. 'The right to respect for private life is not only the right to remain in one's home and exclude others, it is also the right to go out of one's home and meet others." ${ }^{30}$

29 Pamela Samuelson, Privacy as Intellectual Property? , (2000), SLR 52(5) 1125-1173.

30 Francoise Tulkens, 'Freedom of expression and information in a democratic society and the right to privacy under the European Convention on Human Rights: a comparative look at Articles 8 and 10 of the Convention in the case-law of the European Court of Human Rights', in "Freedom of Expression And The Right to Privacy” Strasbourg Conference Reports 23 September 1999 (1999) 32. 
The form and kind of dwelling and it's quality is not important, as its form and quality differs from time to time and from one place to another one, but man could regard it as a dwelling. So, if somebody uses his car as a dwelling, it will be respected, "any place in which, man resides and can lay, sleep, eat, study, work and rest in it without any kind of nuisance, will be regarded as dwelling." 31

The ownership of the dwelling is irrelevant and the legislator only considers the right to use it, whether the individual has hired it or has been allowed to use it free of charge. So, a tenant has the same right as the owner has. Because, here it is not the property, but the welfare and the right to rest that is respected. So there is no difference between different kinds and forms of a dwelling. Even, it could be said that, if somebody occupies a dwelling and resides there, the owner cannot breach the right of the occupier to his privacy and he has to refer to the judicial authorities to terminate the occupation.

\subsubsection{The Realm of Dwelling}

The question here is whether the dwelling includes both the earth and the space over it? In other words, if somebody enters over the space of the dwelling, can we say that he has infringed the right to privacy? For example, if somebody passes over the dwelling through airplane, parachute can we regard it as an infringement to the right of privacy?

According to the Article 38 of the Iranian Civil Code "the ownership to the land includes all its parts and dimensions whether air space or underground and the owner can have all kinds of possession in the land and air space unless the law provides otherwise." So, "the owner can restrain others from any possession in the land and its air space." 32

But, it seems that this Article does not restrain others to use the air space of the dwelling. In other words, in cases that there is conflict between the owner's right and the third parties' right, the owner has the priority but in other cases the owner can not deter others from using the air space of the dwelling. For example, if the third party uses the air space of the dwelling to look at the owner's private life and controls his movements, it could be regarded as an infringement to the right to the privacy.

It could be said that article 38 is not compatible with modern world realities and

31 Abraham Pad, Private Criminal Law (Volume first Tehran University publishing 1973) 291.

32 Naser Katouzian, Iranian Civil Code in the current law Order (Tehran Dadgostar Publishing 1998$) 51$. 
had been written according to thoughts that refer to old times. In other words, since the earth is spherical, we cannot draw an unlimited depth and air space for it. Because, if an owner wants to have possession of unlimited in the depth, this may finally lead him to others' land and if we imagine possession of unlimited air space, this may, in practice, lead him to others air space which will be in conflict with others rights.

In English Law, "in 1815 Lord Ellenborough expressed his opinion in Pickering v Rudd that it would not be a trespass to pass over a man's land in a balloon. The matter was examined more recently by Judge Griffiths J in Bernstein v SKY News Ltd. In that case the owner of a country house in Kent was offered a photograph of his house which had been taken from an airplane flying over the property. The owner objected and brought an action against the defendants who carried on the business of taking aerial photographs of properties of all types and then offering them for sale to the owners. It was alleged that the defendants had wrongfully entered the owner's air space to take a photograph of his house and were thus guilty of trespassing and an actionable invasion of his right to privacy. But the judge dismissed the action and said that he could find no support for the view that the owner's rights in the air space above his property extended to an unlimited right." ${ }^{\text {33 }}$

\subsubsection{The Significance of the Dwelling}

In Iran the dwelling is respected mostly according to custom, but, in addition the law has also provided some provisions in the Constitution and statutes to protect it, as follows:

(1) Article 22 of the Constitution has explicitly referred to the protection of dwelling and has separated the dwelling from other properties. The reason is that, maybe the user of the dwelling as a person who has the right to the privacy, does not own the dwelling and maybe has hired it or has even illegally possessed it. But, the Law respects and protects it and the plaintiff can refer to the Justice.

(2) According to Article 580 of the Islamic Penal Code official entrance to a dwelling without the user's consent is considered a crime with 1-3 years imprisonment and if the trespassing occurred at night the maximum punishment will be provided. Article 694 of this Penal Code punishes the entrance of non-official to a dwelling with threat and violence from 6 months to 3 years imprisonment. 
(3) In articles 139-145 of the code of criminal procedure there are some protective rules regarding dwelling.

\subsubsection{The forms of breaching the right to privacy of the dwelling}

\subsection{Controlling by Camera}

The mentioned provisions about the right to privacy of the dwelling in Iranian law do not include all forms of breaching the right to privacy inter alia controlling the house by long-distance cameras, especially at night.

Regarding phrases like "public order, welfare" in Article 618 of the Islamic Penal Code is inferred that the nuisance should be much wider to be called that the public order has been breached. We therefore cannot regard as a crime the act of annoying a neighbour in a building who plays his cassette-player loud in a building or does unusual movements in his home but annoys the neighbours.

\subsection{Looking}

Sometimes infringement of the right to privacy is done by homes and the movements of the people who live in it. Watching homes by using a long-distance camera is one of the most common ways of infringement of the right to privacy at home. This kind of infringement is usually done by those who are interested in watching.

Iranian Law has not criminalized watching people's houses. But, in one case the court tried to punish a person (according to Article 638 of the Islamic penal code) ) $^{34}$ who had looked at somebody's house through a trapdoor while the owner of the house was having sexual intercourse (private life covers the right to lead one's life, including one's sexual life, without any external interference) (Turkens, p. 30) with his wife at night. But, in fact, this article does not include such acts.

The court's action indicates that there is a gap between the law and society. Society expects the legislator to protect these forms of privacy, and the judge as a reasonable member of society who has an understanding of this problem tries to fill the gap with a broad interpretation of the law, something that is forbidden in criminal law, as the interpretation of a criminal code should not be broad. According to a verdict issued from General Criminal Court, branch 5 in Waramin: One night while the woman and

34 According to this section whoever commits an Islamic illegitimate act in the public places will be punished by imprisonment from 10 to 60 days or till 74 lashes. 
her husband were having sex, the accused had watched their sexual intercourse through a trapdoor and had committed an act forbidden in Islam, ${ }^{35}$ so he was convicted according to article $638 .{ }^{36}$

\subsection{The Right to privacy to Cars}

The right to privacy regarding cars could be considered from two points of view. One of them is vehicle monitoring. 'Automobiles are a separate potential target of blanket surveillance. So-called "intelligent transportations systems" (ITS) are being introduced in many urban areas to manage traffic flow, prevent speeding, and in some cases implement road pricing or centralized traffic control. Ultimately, ITS promises continuous, real-time information as to the location of all moving vehicles. Less complex systems already create travel records that can be stored and accessed later. Some countries have also considered putting barcodes on license plates to ease vehicle identification. While it is possible to design ITS in a manner that preserves the traveller's anonymity, this has not been the norm. ${ }^{37}$

Regarding the monitoring of vehicles, that is done to control the speed of the cars on the roads, the rule is that the police informs the drives of the surveillance of the cars by camera. The justification which could be presented is that to preserve the health of the passengers, the police has to monitor the speed of the cars. In fact, the police by informing the drivers of the installation of the camera want to say that everybody who drives on the Highway accepts to be monitored and his privacy is not infringed.

The other point refers to the searching of cars, which apparently strongly infringes the right to privacy. In Iranian Law, according to Article 55 of the Criminal Procedure Act, in order to inspect the cars in non-obvious offences the law enforcement officers need the order of a judge. But, in practice they do that without getting an order.

35 Forbidden act is any act that is prohibited by the Shari'a. For example, the Sharia has forbidden the search of others in the home. According to verse number 12 of Sura Hojarat "spy not, neither backbite one another".

36 According to Article 638: whoever publicly commits an action that is forbidden in Islam, in addition to the punishment of the action (for example he commits a sexual intercourse publicly), he will be convicted to the imprisonment from 10 to 60 days or flogging from 1 to 74 lashes, and in the case the action per se is not a crime (for example a man has a sexual intercourse with his wife or kisse his sister) but is regarded an indecent action, the perpetrator will be punished from 10 to 60 days imprisonment or from 1 to 74 lashes.

37 A. Michael Froomkin, The Death of Privacy? (2000), SLR 52(5).

${ }^{12}$ Freedom of expression and the right to privacy, Strasbourg Conference 23 September 1999, Conference Reports, pp. 1461-1543. 


\subsection{The Right to Privacy to Physical and Psychological Integrity}

\subsection{The Right to Privacy to Physical Integrity}

The secrets of the body are for the most part medical secrets. For example, when somebody has a disease and would not like others to know, especially, -when society may judge opinion, it would be considered as secrecy. In Iran it is a common belief that whoever has Aids has had illegal sexual intercourse. The following aspects of the body can be regarded as objects of the right to privacy.

\section{(1) Physical Inspection}

One of the objects of the right to privacy is the human body. Regarding the examination of the body (especially in the case of sexual crimes) Article 136 of the Criminal Procedure Act provides "for examining the corpse, wounds and effects and signs of the beating and corporal or psychological damages and other examinations and medical tests, the judge asks the coroner and if he cannot attend or there is no coroner in access, the Judge would ask other doctors to perform the examination. If the coroner is not specialist, a specialist would be called."

But, about corporal inspection no provisions exist in the Criminal Procedure Act and it is very common that Police officers inspect suspected people without any hesitation in the street. Nearly in some important official offices such as the Judiciary, Police stations and Military Offices entering people are inspected.

Physical integrity also includes a person's appearance like his or her clothes and identity. In the following part we will consider these.

\section{(2) The right to privacy to Clothes}

There is no doubt that a person has the right to choose his or her favourite clothes including its size, colour and quality which are chosen it in accordance with the common custom and the social class to which that person belongs.

Iranian Legislator, whether before or after the Islamic Revolution in 1979, has intervened in the quality and quantity of clothing. The first intervention refers to the Act titled "The Unification of Iranian Dressing" ratified on 1928/12/27. According to this Act "all Iranian males who do not have special clothes, have to wear some kind of unified dressing and all employees have to wear specific clothes in accordance with their job during work time (for example the judges and lawyers had special clothing) and in their free time they have to wear public unified 
clothing. Whoever breaches this Act will be punished with imprisonment from 1 to 11 days."

After the 1979 revolution, the Islamic Legislator abolished this Act but deterred people from wearing certain clothes that are un-Islamic or which may offend public sentiment. According to the Article 4 of the Act ratified on 1986/3/18 "those people who wear certain clothes which are anti-Islam or their make-up outrages public feelings or encourages sexual crimes should be arrested and tried and punished"

\section{(3) The right to privacy to identity}

Identity includes the name and family name, identity card number, address, and phone number. In Iranian Law there is no provision to protect people against the infringements that are applied to their identity but the culture respects it. Regarding phone numbers, it should be noted if the owner of the phone has not prevented the communication office from publishing his phone number they cannot protest the publication of their phone number. When the communication office publishes phone numbers in a book named yellow pages it is no longer private, otherwise it is regarded as part of the right to privacy. 'The protection of privacy by legislation or by the courts has always been a reaction to technical and social development. For example, the right to the protection of one's own image has been a reaction to developments in camera engineering, which makes it easy to take pictures of people. The introduction of data protection rules has been a reaction to the processing of personal data by means of computers.' 38

Sometimes it is good for people that their identity characteristics to be published in the media. For example, political candidates in an election are satisfied to have their identification, photos and ideas published in the media, since it is the best way for them to advertise and is moreover a requirement for the election. 'In this series of events we can see political evolution at work. ${ }^{39}$

Another aspect of the right to privacy could refer to the identity regarding Genome. "The concept that "DNA has the power to identify the guilty and exonerate the innocent" is widely accepted." 40

38 Prinz (n 4) 67.

39 Morris L. Ernst and Alan U Schwartz, Privacy, (The Macmillan Company 1962), New York, p. 125.

40 Rahime Erbaş, 'The Tension between Genome Privacy and Criminal Justice in the Wake of DNA Databases' (2017) 5(2) Journal of Penal Law and Criminology 163, 178. 


\section{(4) The right to privacy to opinions}

Iranian Constitution in Article 23 provides:

The investigation of individuals' beliefs is forbidden, and no one may be molested or taken to task simply for holding a certain belief. But in practice, sometimes and in some cases, some governmental entities investigate about the right to privacy in the field of religion. So, it seems that in some cases there is a contradiction between the law and the practice and in fact the right to privacy in the field of beliefs is infringed. The other field of these kinds of rights could be the political one and one of the prominent facets of this field could be an investigation of people's opinion in elections, to detect who they have voted for. In fact it should be said that in Iran very seldom has it been heard that people have been inquired about their opinion to a certain candidate at the time of voting, because the election law has forbidden it and regards it a crime to inquire about the voting and has referred to the secrecy of the vote.

\subsection{The right to privacy to psychological integrity}

The right to privacy to Psychological integrity includes secrets, thoughts and respect which are examined as follows:

\subsection{The right to privacy to secrets}

Article 648 of the Islamic Penal Code provides "Doctors, Surgeons, Midwifes, Drug sellers and all persons who have a job which makes them aware of people's secrets, upon revealing the secret, will be sentenced to 91 days to 1 year imprisonment and the payment of a fine between 1500000 to 6000000 Iranian Rials (roughly equivalent to US\$17-60).

So, as it is inferred from this article, revealing the secrets by those who have got them not because of their job is not an offence. Also, article 698 of the Penal Code, only punishes publishing lies about people. So, if somebody publishes secrets about another person and the published matters are not lies, then the author will not be punished.

\subsection{The right to privacy to thoughts}

Modern law acknowledges man's right to his/her thoughts and regards it as a form of ownership. In Iranian Law some Acts like the Act of registering the Signs and Inventions ratified on 1931/6/21 and the Act of protecting the Compilers, Authors 
and Artists ratified on 1961/12/31 and the Act of translation and multiplication of books and magazines and Sounds ratified on 1973/12/25 have provided some provisions to protect man's thoughts. These Acts criminalize piracy.

Regarding thoughts, according to article 23 of the constitution, Inquisition of the beliefs is forbidden and nobody could be interrogated for having a belief.

\subsection{The right to privacy to communications}

Man's right to privacy has created some new areas including the right to his/her writings and letters and phone communications.

\section{(1) Letters and writings}

Writings may have different forms such as letters to others or some scientific matters. Regarding letters both Constitution (article 25) and Statutes (article 582 of the Islamic Penal Code) have protected the right to the privacy.

Article 582 as a criminal sanction for article 25 of the Constitution provides that "any official employee who opens, restrains, destroys, inspects, records or bugs or reveals people's letters, communications including telephone and telegraph illegally or without consent of the owners will be sentenced to 1 to 3 years imprisonment or 6000000 to 18000000 Rials fine (60 to 180 USA Dollars). But this article does not protect the right to privacy in the case the perpetrator is not an official employee.

\section{(2) Phone communications}

According to the Notice of the article 150 of the Criminal Procedure Act bugging the phone communications is forbidden except in the cases of country-security crimes or to detect serious crimes which requires the permission of the head of judiciary of the related province. Regarding the high grade authorities mentioned in article 307 it is necessary to get the permission of the head of the judiciary.

\section{Conclusion}

In conclusion, it could be stated that although the importance of privacy is deeply ingrained in our cultural heritage, the right of privacy is not explicitly mentioned in the Constitution and statutes and only they have referred to a few cases of this right.

Also, it could be said that in a few cases that have been mentioned the legislator has not protected all dimensions of the right. For example, in articles 648, 694,698 and 582 of the Islamic Penal Code the legislator has only considered some aspects 
of the right. In article 648 only revealing the secrets by people who become aware of the secret because of their jobs have been criminalized. In article 694 only entrance with threat and violence has been regarded a crime. In article 698 only publishing the lie is a crime but publishing secrets as long as they are true, is not criminal. Article 582 only refers to the officials and not the non-officials and a more important problem is that the legislator has not provided criminal sanctions for breaching the right to privacy and even in most cases has not provided a Civil sanction. In fact, Iranian Law does not affirm the 'right' of the people to be secure in their persons, houses, papers and effects against unreasonable searches and seizures. People expect the State to guarantee their privacy. Therefore, although respecting privacy is mainly a cultural concept, when people consider that there is no official support, they may not respect it as better as when there is an official support. As we see, 'although privacy is often referred to as a human right, conflicts with freedom of expression are far more common in the context of privacy as the subject of statutory protection. This is because as a human right, privacy relates primarily to State, not private, actions. The obligations human rights guarantee impose on States to protect individuals against possible invasions of their privacy by other individuals are very limited'. ${ }^{41}$

\section{Bibliography}

Ashouri M, Criminal procedure (First Volume Samt Publications 2016).

Ashworth A, Principles of Criminal Law (Tony Honore \& Joseph Raz eds, Clarendon Press, Oxford 1992) 302.

Bennet C J, Regulating Privacy (Cornel University Press 1992).

Bakırman Demiral B, 'The Protection of Trade, Banking, and Customer Secrets in Turkish Criminal Law' (2017) 5(2) Journal of Penal Law and Criminology.

Erbaş R, 'The Tension between Genome Privacy and Criminal Justice in the Wake of DNA Databases' (2017) 5(2) Journal of Penal Law and Criminology .

Ernst M L, Schwartz A U, Privacy (The Macmillan Company 1962).

Ettienne P, ‘The Right to Privacy in French Law' in Basils Markesinis (eds), (Clarendon Press Oxford 1998).

Evan H, Your Right to Privacy (2 $2^{\text {nd }}$ edn, South Illinois University Press 1999).

Froomkin A M, 'The Death of Privacy?' (2000) 52 SLR.

"Freedom of Expression And The Right to Privacy" Strasbourg Conference Reports 23 September 1999 (1999).

Guido A, 'Protection of Privacy in Italian Law' in Basils (edn) Protecting Privacy, (Oxford University Press, 1999).

Hofstadter S H, The Right of Privacy (Central Book Company 1964).

Katouzian N, Iranian Civil Code in the current law Order (Dadgostar Publishing 1998).

Maureen S \& Nutcases S, Human Rights (Sweet \& Maxwell 2002). 
Neil B, Privacy A, 'Challenge for the Next Century' in Basils Markesinis (eds), Protecting Privacy (Clarendon Press 1998).

Samuelson P, ‘Privacy as Intellectual Property?' (2000) 52, SLR.

Pad A, Private Criminal Law, (First Volume, Tehran University Publishing 1973).

Council of Europe 1973 Report of the committee of experts on human rights to the committee of ministers on the right to respect for privacy, Strasbourg.

Rubenfeld J, 'The Right of Privacy' (1989) 102 HLR 707,807.

Tulkens F, 'Freedom of expression and information in a democratic society and the right to privacy under the European Convention on Human Rights: a comparative look at Articles 8 and 10 of the Convention in the case-law of the European Court of Human Rights, in Freedom of expression and the right to privacy' (Strasbourg Conference 23 September 1999).

Wasby S L. Introduction: Civil Liberties and policy making. (1976) In S. L. Wasby (Ed.), Civil Liberties (pp. ix-xiv). London: Southern Illinois University Press. 
